\title{
Pharmacy Education in Egypt
}

\author{
Nour SA* \\ Professor of Pharmaceutics, Faculty of Pharmacy, Cairo University, Cairo, Egypt \\ *Corresponding author: Samia A Nour, Professor of Pharmaceutics, Faculty of \\ Pharmacy, Cairo University, Cairo, Egypt, Email: samia.nour@pharma.cu.edu.eg
}

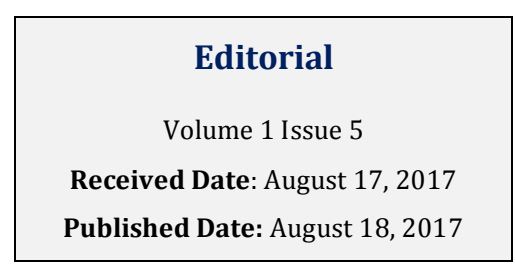

\section{Editorial}

Egypt is a developing nation that occupies an important geographic and historic position in the heart of the Middle East. It is located in the cross roads between Africa, Asia and Europe. Its population is approximately 100 million.

\section{Pharmacy Education in Ancient Egypt}

The ancient Egyptians knew many therapeutic effects of the medicinal plants. This knowledge was taught at home from father to son. These houses formed the first primitive pharmacy and medicine schools. This was then developed into establishment of medical and pharmaceutical schools in the temples and some priests were chosen to become teachers in these schools.

\section{Pharmacy Education in Egypt Modern History}

The first educational institution for pharmacy in Egypt in the modern history was founded in Abou Zaabal (a suburban area near Cairo) in 1824 and 25 pharmacists were graduated in the year 1832 after five academic years study. The institution has been transferred to Kasr ElAini street (its current location) in 1837. Later in 1925, the school was affiliated to Fouad I University and became known as faculty of medicine. In 1955, a governmental decree was issued to establish a faculty of pharmacy independent off faculty of medicine. By that time Fouad I University had then become known as Cairo University. Few government schools of pharmacy were then established in the following years in different cities in Egypt.

\section{Growth of Pharmacy Education}

Prior to mid 1980s, the growth of the governmentally funded pharmacy schools was slow. Since the late 1980s, due to rapid industrialization in pharmaceutical sector, privatization and economic growth in the field of pharmaceuticals, pharmacy education has been fast developing in Egypt. In the year 1996, the regulations permitted the establishment of private universities. In the year 2016, there were 44 faculties of pharmacy affiliated to governmentally and privately funded universities. 16000 students were admitted to the B Pharm degree programs and several hundreds to the post graduate degrees. Admission to the first year B Pharm program is made directly from higher secondary school on the basis of the marks obtained in the final exam.

\section{Educational Programs}

A variety of pharmacy degree programs are offered in Egypt, namely: Bachelor of Pharmacy (B Pharm), postgraduate Diplomas in pharmacy, Master of Pharmacy (M Pharm), Doctor of Pharmacy (Pharm D) and Doctor of Philosophy in Pharmacy (PhD). Pharmacy education in Egypt traditionally has been industry and product oriented. The concept of pharmacy practice was then realized and clinical pharmacy courses were included in the curriculum to support the graduation of pharmacists to work in the community pharmacies and health care settings as well as in pharmaceutical industry.

\section{Regulations and Quality Issues}

Pharmacy education in Egypt is regulated by Ministry of Higher Education (MOHE), Supreme Council of Universities (SCU) and Pharmacy Sector Committee (PSC). The quality assurance of pharmacy programs is maintained through accreditation by National Authority for Quality Assurance and Accreditation of Education (NAQAAE). Ministry of Health and Egyptian Syndicate of Pharmacists are responsible for registration of the 
persons fulfilling the prescribed eligibility criteria (minimum B Pharm) and issuing license permitting them to practice as pharmacists in Egypt. Unlike other countries the current regulations do not require any continuing education to maintain licensure once they are offered.

\section{Summary}

Pharmacy education in Egypt continues to be one of the first options for students aiming at a university degree.
The profession developed from being an industry and product oriented one to be a patient oriented as well. Pharmacy education has expanded in terms of number of institutions offering various pharmacy programs at different levels. The pharmacy curriculum cover many disciplines which offers the pharmacy graduates the opportunities to work in production, management, quality assurance, marketing, regulatory affairs as well as community and institutional pharmacy. 